\title{
Annual Report for 1974
}

Membership has continued to increase steadily, and stood at 3419 at the end of the year. Of the 351 new members elected, nine took out benefactor membership (minimum subscription $£ 10$ ) and one became a life member. 31 deaths were recorded. The 276 resignations and deletions included 19 life members with whom we have had no contact over the last five years and who were, in accordance with the Society's rules, removed from the membership list.

\section{Presidency}

Our President for the last 23 years, the Marquess of Willingdon, stepped down from office at the Annual General Meeting in July but retains his close connections with the Society as President Emeritus, an office to which he was unanimously elected. The new President is Professor Lord Zuckerman OM KCB DSc FRS, who has been a Vice-President of the Society for eleven years and Secretary of the Zoological Society of London for 19 years.

\section{ORYX $100 \%$ Fund}

Donations during the year totalled $£ 3584$, including $£ 1596$ in earmarked gifts. The doubling arrangement started in 1972 finished towards the end of the year when the total of unearmarked donations reached $£ 5000$. $£ 6929$ was paid out to the 20 projects listed in the audited accounts of the Fund on page 106. Aid was given for the study of threatened species, including crocodilians and river turtles in Colombia, Calamian deer in the Philippines, marine turtles in the Indian Ocean and northern swamp deer in Nepal; for investigations into animal trade in Liberia and trade in cheetahs in South Africa; for antipoaching work in Ghana, India and Kenya; and for conservation education in Argentina, Chile (as part of the vicuña campaign) and Ghana. Other grants went to the rehabilitation of captive chimpanzees in Senegal, and projects in Indonesia, Kashmir, North Africa, Panama, Peru, Rwanda and Scotland.

\section{Endangered Species Fund}

Four grants were made in 1974: $£ 200$ to the ICBP for the study of marine turtles on Cousin Island, in the Seychelles, $£ 150$ for rewards provided by the Trinidad and Tobago SPCA to protect nesting turtles on Tobago, $£ 35$ to the Jersey Zoo to provide an educational display board on the Gir lions presented by the FPS in 1972, and $£ 30$ to Dr Shirley McGreal in Thailand for a survey of the animal traffic through Bangkok airport.

\section{Legacies and donations}

A further $£ 1302$ was received from the estate of the late Captain J. J. Toller. Other legacies were $£ 100$ from the late H. H. Davis, $£ 61$ from the late C. T. A. Maberley, and $£ 50$ from the late Dr Allen B. Bratton, in whose memory we also received donations of $\mathfrak{6 6 7}$. Generous donations included a third anonymous annual grant of $£ 2000$, $£ 500$ from Mrs. E. L. M. Barbour Paton, $£ 250$ from the St Katharine's Fund, $£ 200$ from Eric de Rothschild, $£ 100$ each from Lady Sarah Aspinall and the New Moorgate Trust Fund, $£ 50$ from the Ernest Kleinwort Charitable Trust, $£ 32$ from John D. Constable, $£ 30$ from 
S. F. Wynne-Eyton, $£ 26$ from Miss G. Parlier, and $£ 25$ each from M. R. Gliksten, M. J. Hayne, B. C. Le May, the Richard Hanbury Tenison Charitable Trust and the Pamela Sheridan Charitable Trust.

\section{Arabian Oryx World Herd}

The main part of the herd, housed at Phoenix Zoo, Arizona, totalled 17 males and 19 females (three calves of each sex having been born during the year). Three calves have been born in the nucleus herd at San Diego Zoo, California, moved there in November 1972, which now totals eight.

\section{Wildlife Tours}

In July Sir Hugh Elliott led the first FPS tour (which was also the first British tour) to Rwanda and Zaire the highlight of which was wild mountain gorillas. In August some 15 members joined in a tour to the Galapagos Islands and Ecuadorian upper Amazon basin, arranged by Peregrine Holidays.

\section{Meetings}

The Hon. Secretary and Editor attended two meetings of the Survival Service Commission in Morges, in May and October, and the Hon. Secretary attended Alert Group meetings held immediately prior to these and a meeting of the Whale Group also held in Morges in May. In June he represented the Society at the 26th International Whaling Commission meeting in London. In September, in his personal capacity, he was a member of the British Delegation to a GB/USSR Association Conference held in Yerevan, in Soviet Armenia.

\section{Representation}

Representation of the Society on other bodies continued to be as set out in the 1973 Annual Report, Oryx June 1974, p. 498.

\section{Meetings of the Society}

The Annual General Meeting on July 3rd attracted more than 250 members and friends. The speaker was Lord Garnsworthy, Government environment spokesman in the House of Lords, deputising for the Rt Hon. Anthony Crosland who was prevented from coming by an important debate in the House. The new President, Professor Lord Zuckerman, took the chair.

In January Dian Fossey talked about her work with mountain gorillas in Rwanda and showed a superb film, and John Owen introduced and spoke to George Schaller's film on the Serengeti. John Aspinall was the speaker in March and showed a film on his animal collection at Howletts; in addition the National Film Board of Canada's excellent film on wolves, Death of a Legend, was shown. A copy of this film is now in the FPS film library. At a meeting in September, Jeffery Boswall introduced the BBC film The Private Life of the Grey Seal and the Countryside Commission for Scotland's Who Cares for Scotland? was also shown. In addition members saw slides taken by participants on the successful tours to Rwanda and Zaire and the Amazon Basin and Galapagos Islands.

At the final meeting of the year, in November Dr R. D. Martin gave an illustrated talk on the conservation of Madagascar lemurs, and $\mathrm{Dr}$ John MacKinnon spoke to his own film on orang-utans and other animals of the 
South-East Asia rain forest. A wine and cheese supper was served at each meeting, and their popularity was as great as ever.

During the autumn two additional meetings were held away from the Zoo, one in Hampstead where W. H. Meadows arranged an evening of wildlife films, and one in Sevenoaks, where Robert Hards gave an illustrated talk on a wildlife safari to Zambia. We are most grateful to these two members for their efforts and for the resulting donations to the Oryx $100 \%$ Fund.

\section{Film Library}

There were 181 bookings during the year. The Everglades Region was purchased and new copies of To Catch a Rhino and Lake Wilderness added to the library through the generosity of the South African Tourist Corporation.

\section{Christmas and Other Sales}

48,440 Christmas cards were sold. We are most grateful to Ralph Thompson who painted the white-handed gibbon and to Denys Ovenden who drew the dormouse especially for our cards. A key chain bearing the oryx head symbol and FPS name and address was on sale for the first time, and two new sets of memo pads with animal drawings by Robert Gillmor and Diana Brown are selling well. We are extremely grateful to both of these artists for allowing us to use their work in repeating this very popular item.

\section{The Zoological Society of London}

The Zoological Society of London has continued to offer help and kindness throughout the year in addition to its much appreciated provision of office accommodation and services, for all of which the Society is most grateful. 


\section{Auditors' Report}

\section{To: The Council and Members of the Fauna Preservation Society}

Accounts for the year ended 31st December 1974

We have completed the audit of the books and accounts of the Society for the year ended 31st December 1974 and report thereon as follows:

\section{Life Membership Fund}

The balance standing to the credit of the Fund is now $£ 11,492$. This is after crediting $£ 150$ in respect of Life Membership Subscriptions received during the year and transferring $£ 435$ to the General Reserve Account, the subscriptions of those whose life membership ceased during the year.

Film Purchases - Reserve Fund

A transfer from Income and Expenditure account of $£ 225.85$ was added to the opening balance $£ 870.66$ and from this total of $£ 1,096.51$ was deducted purchases of $£ 117.84$. The balance to be carried forward is $£ 978.67$.

Fedangered Species Fund

The balance at 1st January 1974 was

Expenditure during the year was

$£ 1,139.53$

leaving a balance to be carried forward

£723.89

Inflation Reserve Fund

This Fund has been opened during the year with a transfer of $£ 2,000.00$ from Income and Expenditure Account.

General Reserve Account

The balance at 1st January 1974 was

29,361.37

to which has been added:

\section{Legacies}

Fees of deceased life members

Surplus from Income and Expenditure account

Loss on sale of investments amount to

giving a balance at the year end of
$1,514.05$

435.00

118.06

$2,067.11$

$31,428.48$

$2,144.46$

$\lcm{£ 29,284.02}$

In 1973 investment income of $£ 1,602.49$ was re-invested and added to General Reserve Account. In 1974 all investment income is credited to the Income and Expenditure Account.

Investments

The total investments at 31st December 1974 at cost amounted to $£ 43,071.07$

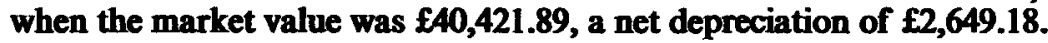

Suplus

The surplus of assets over liabilities at the end of the year amounted to

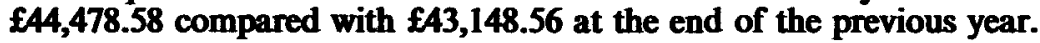

Oryx 100\% Fund

To the balance at 1st January 1974 of $£ 6,873.18$ has been added $£ 2,164.00$ transferred from Income and Expenditure Account and $\mathbf{f 4 , 0 3 4 . 4 2}$ from Donations and Interest, making a total of $£ 13,071.60$. Grants amounting to $\mathbf{f 6 , 9 2 9 . 5 3}$ have been made during the year, leaving a balance of $\mathbf{1 6 , 1 4 2 . 0 7}$. 


\section{BALANCE SHEET}

1973

\section{LIABILITIES}

£

2,793 Sundry Creditors and Provisions

f $p$

Receipts in Advance

739 Subscriptions

3,532

Balance, being excess of assets over liabilities:

$3,443.40$

$1,232.71$

$4,676.11$

Life Membership Fund

Balance at 1st January, 1974

Add: Fees received during year

$11,777.00$

150.00

Deduct: Transfer to General Reserve Account:

$\overline{11,927.00}$

11,777 Fees of deceased Life Members

435.00

$11,492.00$

Film Purchases-Reserve Fund

Balance at 1st January, 1974

870.66

Add: Transfer from Income \& Expenditure Account

225.85

Deduct: Purchases during year

$1,096.51$

Endangered Species Fund

Balance at 1st January, 1974

1,139 Deduct: Expenditure during year

$1,139.53$

415.64

Inflation Reserve Fund

Transfer from Income \& Expenditure Account

General Reserve Fund

Balance at 1st January, 1974

Add: Legacies received during year

Transfer from Life Membership Fund

117.84

Excess of Income over Expenditure for the year

$29,361.37$

$1,514.05$

435.00

118.06

$31,428.48$

29,361 Less: Loss on sale of Investments

$2,144.46$

$29,284.02$

$£ 49,154.69$ 


\section{-31st DECEMBER 1974}

1973

\begin{tabular}{|c|c|c|c|c|c|}
\hline \multirow{3}{*}{$\mathfrak{f}$} & \multicolumn{4}{|c|}{ ASSETS } & \multirow[b]{2}{*}{ p } \\
\hline & & \multicolumn{2}{|c|}{ Sundry Dehtors and Pauments in Adrance } & & \\
\hline & 242 & $\begin{array}{l}\text { Sundry Debt } \\
\text { Income ta }\end{array}$ & $\begin{array}{l}\text { rs and Payments in Advance } \\
\text { recoverable on investments }\end{array}$ & 256.25 & \\
\hline 3,171 & 2,929 & Other & & $3,350.34$ & $3,606.59$ \\
\hline 1,405 & & $\begin{array}{l}\text { Stocks in } H_{c} \\
\text { (at or und }\end{array}$ & $\begin{array}{l}n d \\
\text { er cost) }\end{array}$ & & $1,810.00$ \\
\hline - & & Office Furnit & ure and Fixtures (not valued) & & - \\
\hline & & $\begin{array}{r}\text { Investments } \\
4,136.00 \\
15,887.70 \\
1,050\end{array}$ & $\begin{array}{l}\text { at cost) } \\
\text { Greater London } 91 \% \text { Stock } 1980 \\
\text { Greater London } 71 \% \text { Stock } 1977 \\
\text { Viking Resources Trust Ltd. } \\
\text { 25p shares }\end{array}$ & $\begin{array}{r}4,120.22 \\
13,842.99 \\
1,299.68\end{array}$ & \\
\hline 38,227 & & & Deposits with local authorities & $23,808.18$ & $43,071.07$ \\
\hline 3,877 & & $\begin{array}{r}\text { Balance at b } \\
\text { General a }\end{array}$ & $\begin{array}{l}\text { ank and cash in hand } \\
\text { count }\end{array}$ & & 667.03 \\
\hline
\end{tabular}

We have examined the above Balance Sheet and accompanying Income and Expenditure Account, and the Receipts and Payments Account relating to the Oryx 100\% Fund, with the books and accounts of the Society and with the information and explanations supplied and certify them to be in accordance therewith. We have verified the bank balances and the investments of various funds.

Knightway House

20 Soho Square

London W1V 6QJ

NORTON KEEN \& CO.

28th February 1975

Chartered Accountants 


\title{
INCOME AND EXPENDITURE ACCOUNT
}

\author{
GENERAL PURPOSES
}

1973

⿷

4,385 Salaries-Office Manager and secretarial staff

300 Editor's honorarium

152

769

236

3,780

618 of IUCN

Hon. Secretary's overseas expenses including S.S.C. of IUCN

Hon. Secretary's local travelling

Production of Journal Postage for Journal Editor's expenses including Survival Service Commission

\section{EXPENDITURE}

Rent of offices-

Regent's Park

- Less: Donation from Zoological Society

616 Office and miscellaneous expenses

491 Stationery

356 Telephone

120 Advertising

735 Postage

38 Films-insurance

120 Accountancy and audit

105 Income tax-accountancy charges

389 Grants and subscriptions to other bodies

3,697 Transfer to $100 \%$ Fund

719 Transfer to Endangered Species Fund

- Conference expenses

- Transfer to Inflation Reserve Fund

Balance-excess of income over expenditure carried to Balance Sheet

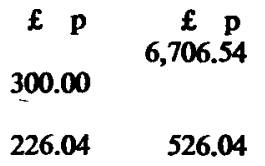

401.58

212.02

$4,629.47$

$1,149.64 \quad 5,779.11$

250.00

250.00

17,863

300.72

377.03

466.11

61.56

599.34

45.40

180.00

25.00

394.65

$2,164.00$

14.50

$2,000.00$

118.06

$£ 20,371.66$ 


\section{for the year ended 31st DECEMBER, 1974}

\section{ACCOUNT}

1973

$\boldsymbol{f}$

\section{INCOME}

\begin{tabular}{|c|c|c|}
\hline 9,788 & $\begin{array}{l}8,741 \\
1,047\end{array}$ & $\begin{array}{l}\text { Subscriptions- } \\
\text { Current } \\
\text { Tax recovered on Covenants 1973/74 }\end{array}$ \\
\hline $\begin{array}{r}4,399 \\
1,316 \\
778\end{array}$ & & $\begin{array}{l}\text { Donations } \\
\text { Interest on Investments (Gross) } \\
\text { Journals - sales and advertisements }\end{array}$ \\
\hline 1,202 & $\begin{array}{l}2,500 \\
1,298\end{array}$ & $\begin{array}{l}\text { Christmas Cards-sales } \\
\text { Less: Cost of production and postage }\end{array}$ \\
\hline 380 & & $\begin{array}{l}\text { Sundry sales-net } \\
\text { Films-handling charges - net income }\end{array}$ \\
\hline - & & $\begin{array}{l}\text { Less: Transferred to Film Purchases Reserve } \\
\text { Fund }\end{array}$ \\
\hline - & & Miscellaneous Income \\
\hline
\end{tabular}




\section{Oryx \\ ORYX $100 \%$ FUND \\ Year ending 31st December, 1974}

INCOME

Balance at 1st January 1974

$\stackrel{f}{f} \mathrm{p}$

Income for year-

Donations

Transfer from General Fund

584.42

Loan interest

\section{GRANTS}

Rehabilitation of captive chimps, Senegal (Stella Brewer)

968.00

Study of crocodilians and river turtles, Colombia (R. W. Foote)

500.82

Study of cheetah status and skin trade, South Africa (J. D. Skinner)

500.57

Calamian deer study, Philippines (Ian R. Grimwood)

500.00

494.70

Camping equipment for anti-poaching teams, Ghana (Chief Game \& Wildlife Officer)

494.00

Anti-poaching arrangements, Dudwa Sanctuary, India (Arjan Singh)

401.17

Vicuña conservation education campaign, Argentina and Chile (WWF)

Marine turtle survey, Indian Ocean (Jack Frazier)

385.56

350.00

Common seal study, Scotland (Susan Fogden)

Outboard motor purchase, anti-poaching boat, Lamu, Kenya (EAWLS)

Operation Hangul, Kashmir (Cambridge World Wildlife Study Centre)

300.00

300.00

300.00

Barbary ape distribution study, North Africa (David Taub)

258.81

250.57

250.00

Northern swamp deer study, Nepal (Dietrich Schaaf)

250.00

Expedition to Manu National Park, Peru (Durham University)

250.00

Establishment of technical research library, Ghana (Department of Game and Wildlife)

127.33

Study of coral reef fish, San Blas Islands, Panama (Oxford Biological Expedition)

Operation Tiger (WWF)

Balance at 31st December-Local Authority loans

$£ 6,929.53$

Balance at bank 


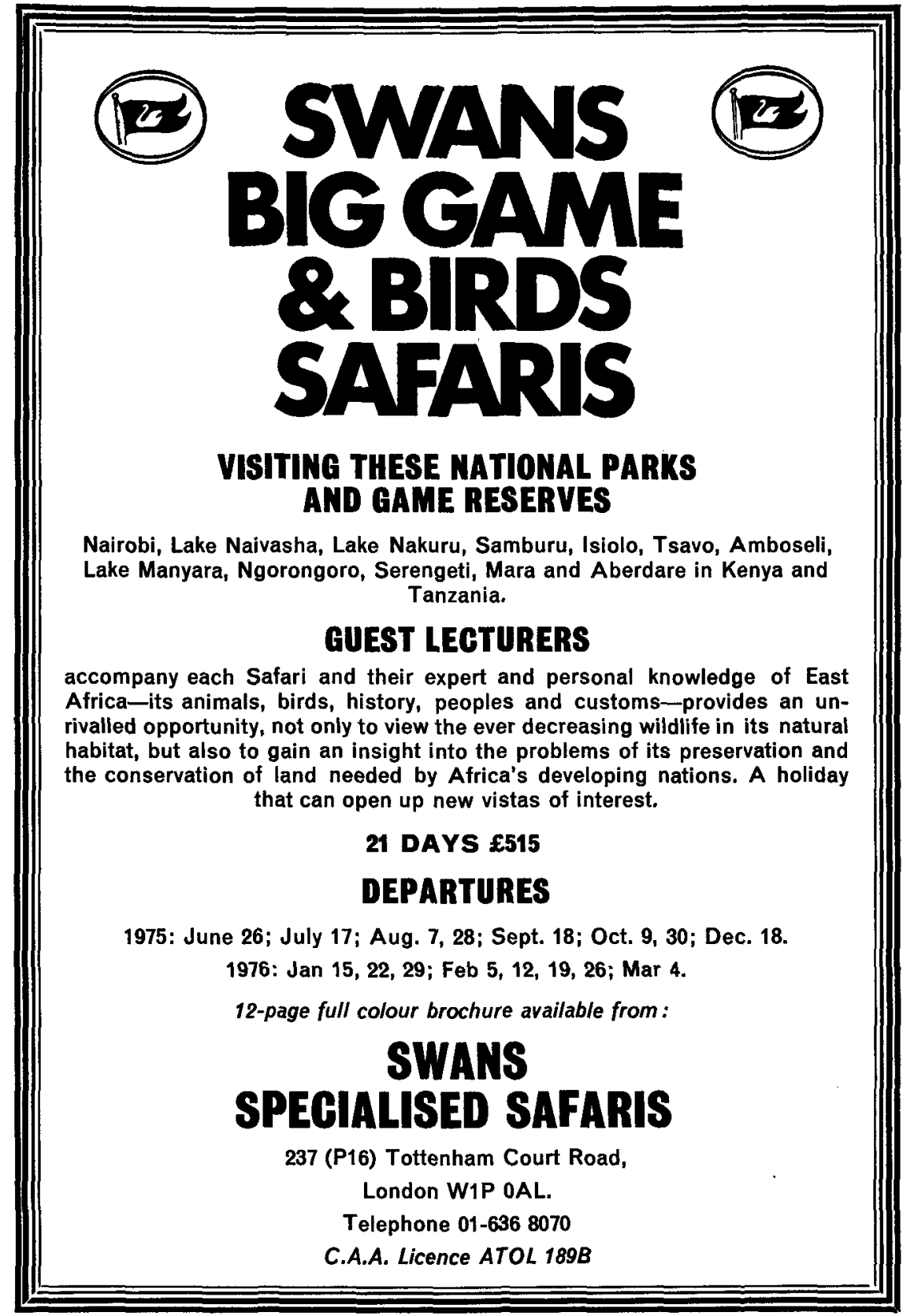




\title{
Journal of Applied Ecology
}

\author{
Edited by \\ T.H. Coaker and R.W. Snaydon
}

Volume 12, Number 1, April 1975 (Contents)

B. N. K. Daois. The colonization of isolated patches of nettles (Urtica dioica L.) by insects M. Lewellyn. The effects of the lime aphid (Ewcallipterus tilioe L) (Aphididae) on the growth of the lime (Tilia $x$ oulgaris Hayne). I. The primary production of saplings and mature trees, the energy drain imposed by the aphid populations and revised standard deviations of aphid population energy budgets $R$. Dean, J. $\boldsymbol{B}$. Ellis, $\boldsymbol{R}$. W. Rice and R. E. Bement. Nutrient removal by cattle from a shortgrass prairie $\boldsymbol{P} . \boldsymbol{M}$. Room and E. S. C. Smith. Relative abundance and distribution of insect pests, ants and other components of the cocoa cocosystems in Papua New Guinea P. M. Room. Relative distributions of ant species in cocoa plantations in Papua New Guinea John A. Wiens and Meloin I. Dyer. Simulation modelling of red-winged blackbird impact on grain crops $\quad J$. A. Bishop, L. M. Cook, J. Muggleton and M. R. D. Seaward. Moths, lichens and air pollution along a transect from Manchester to North Wales J. M. Peacock. Temperature and leaf growth in Lolium perenue. I. The thermal microclimate: its measurement and relation to crop growth $J$. M. Peacock. Temperature and leaf growth in Lotivon peresine. II. The site of temperature perception $\quad P . A$. Gerakis, F. P. Guerrero and W. A. Williows. Growth, water relations and nutrition of three grassland annuals as afiected by drought $P$. C. Annis and G. R. Nicol. Respirometry system for small biological samples $\quad S$. N. Adouns. Sheep and cattle graring in forests: a review U. G. Bokhari, J. S. Singh and F. M. Sminh. Influence of temperature regimes and water stress on the germination of three grasees and its possible ecological significance to a shortgrass prairic R. Elfin Hugher, J. Dale, M. D. Mountford, and I. Ellis Willians. Studies in sheep populations and environment in the mountains of north-west Wales. II. Contemporary distribution of sheep popolations and environment Jomes $N$. Lang and J. Turner. Aboveground biomass of understorey and overstorey in an age sequence of four Douglas-fir stands $\quad B$. R. Treabath. Neighbour effects in the genus Aoenc. III. A diallel approach $W$. $R$. Birch. Some chemical and calorific properties of tropical marine angiospenms compared with those of other plants $\quad D$. S. Mütchell and $N . M . T w$. The rate of growth of Saloinia molesta (S. anciculata Auct.) in laboratory and natural conditions $\quad$ P. V. Biscoe, J. A. Clark, K. Gregson, M. MCGowom, J. L. Mameith and R. K. Scott. Barley and its environment. L.Theory and practice $\quad K$. Gregson and $P$. V. Biscoe. Barley and its environment. II. Strategy for computing $\quad P . V$. Biscoe, $R$. $\boldsymbol{X}$. Scott and J. L. Mantieth. Barley and its environment. III. Carbon budget of the stand P. V. Biscoe, J. N. Gallagher, E. J. Littleton, J. L. Monteith and R. R. Scott. Barley and its environment. IV. Sources of assimilate for the grain $J . N$. Gallogher, $P$. V. Biscoe and R. K. Scott. Barley and its environment. V. Stability of grain weight Sund $\boldsymbol{K}$. Pancholy, Elroy $L$. Rice and Jack A. Turner. Soil factors preventing revegetation of a denuded area near an abandoned zinc smelter in Otlahoma $\quad I . R$. Colquhow and $E$. M. Watson. A modified method of mapping hill vegetation in relation to animal distribution $A$. J. $P$. Gore. An experimental modification of upland peat vegetation A.J. Rutter, A. J. Morton and P. C. Robbins. A predictive model of rainfall interception in forests. II. Generalization of the model and comparison with observations in some coniferous and hardwood stands $P$. R. Shewry and P. J. Peterson. Calcium and magnesium in plants and soil from a serpentine area on Unst, Shetland Reviews

The Journal of Applied Ecology is published three times a year at $£ 11.00(\$ 39.00)$ per issue; subscription price $\mathbf{f 3 0 . 0 0}$ (\$105.00) per annum, post free. New subscriptions and requests for specimen copies should be addressed to Blackwell Scientific Publications Ltd, Osney Mead, Oxford OX2 0EL.

\section{Blackwell Scientific Publications}




\section{East African Wildlife Journal}

Edited by J.B. Sale

Published quarterly at $\mathbf{1 1 5 . 0 0}(\mathbf{S 5 0 . 0 0 )}$ per annum, post free

Contents of Volume 13, Number 1: March 1975

F. I. B. Kayanja and J. B. Sale: The ovary of Gunther's dik-dik, Madoqua guentheri Thomas

J. A. Sayer and L. P. van Lavieren: The ecology of the Kafue lechwe population of Zambia before the operation of hydro-electric dams on the Kafue River

Graeme Caughley and John Goddard: Abundance and distribution of elephants in the Luangwa Valley, Zambia

Peter Waser: Diurnal and nocturnal strategies of the bushbuck Tragelephus scriptus (Pallas)

Linda Pennycuick: Movements of the migratory wildebeest population in the Serengeti area between 1960 and 1973

Subscriptions to either of these journals should be accompanied by the appropriate remittance and sent to Blackwell Scientific Publications Ltd., Osney Mead, Oxford OX2 OEL, England.

\section{Travel Lovers}

* 7-seater microbus (camping equipment supplied).

* Organiser drives every tour personally.

* 5 years' experience and valuable contacts.

* Wild-life, scenery, art and photography.

* Small groups unobtrusive and akin to private travel.

* Your interests, calibre and help add to our success.

\section{Lapland}

3 weeks, Lofoten islands 20 June - 13 July, $£ 165$.

4 weeks, Lyngen peninsula and N. coastline, 26 July - 24 August, $£ 195$.

\section{S. W. Norway}

2 weeks, 12-27 July $£ 104$.

Other tours to: Tunisia, Brugge, N. Italy, Hte. Savoie, Loire and Dordogne.

Write to: Travel Lovers, 6A Limetree Avenue, Weston Green, Thames Ditton, Surrey. 


\section{Application for Membership}

\section{The Fauna Preservation Society}

c/o The Zoological Society of London, Regent's Park, London NW1 4RY

Please enrol me as a member of the Society

Name (BLOCK LETTERS) Please state Mr/Mrs/Miss or title

\section{Address}

\section{I enclose $£$ : :}

being my subscription as a Life/Benefactor/Ordinary Member.

The minimum subscription for Ordinary Members is $£ 3$, US \$7.75, for Benefactors $£ 10$, US \$25, payable on January 1st. A Banker's Order saves time, expense and reminders. The value of any subscription is greatly increased if it is paid under a seven-year Deed of Covenant (UK standard-rate income taxpayers only) and this entails no extra cost whatever: write for Covenant forms to the Secretary.

Life membership fees:

Age: Under 41, £200, US \$485; age 41-60, £150, US \$385; age 61 and over, $£ 75$, US \$185.

\section{Banker's Order}

Bank

Address of Bank

Please pay for the Credit of The Fauna Preservation Society, Barclays Bank Ltd., Camden Town, London NW1, my subscription of $\{\ldots . . . . . . . .$. due on 1 st January, 19 , and a similar amount on 1st January each year until further notice. 


\section{FPS Wildlife Film Library}

Unless otherwise stated all films are $16 \mathrm{~mm}$. in colour with soundtrack, and cost $£ 2.08$ each to hire including VAT. To book a film please write to the Films Officer, Fauna Preservation Society, c/o Zoological Society, Regent's Park, London NW1 4RY. Tel: 015860872.

The Everglades Region: An ecological study of a national park in Florida. 24 mins. f3.00.

To Catch a Rhino. The translocation of white rhinos from the Umfolozi Reserve. SATOUR. 20 mins. $£ 2.62 *$

Lake Wilderness. The wildlife of St Lucia Lakes. SATOUR. 20 mins. $£ 2.62 . *$

The Blesbok : its Life History. The Transvaal Nature Conservation Division. 15 mins. £2.16.

Whales, Dolphins and Men. A BBC Horizon film. The lives of whales and dolphins, and their exploitation. 50 minutes. $£ 6.00$.

Death of a Legend : the wolf in Canada; a challenge to the myth of the wolf's danger to man and an appeal for its conservation. National Film Board of Canada. 50 minutes. $£ 6.00$.

The Peace Game-The wildlife of South Africa. South African Tourist Corporation. 25 mins. $£ 2.62$.

The Uganda Kob-Territorial and mating behaviour, by H. K. and J. H. Buechner. Presented by the Smithsonian Institution. 20 mins. $£ 2.62$.

The Last of the Wild, by Eugen Schuhmacher. 110 mins. $£ 10.00$.

Wildlife for the Future, by Gordon Maclean. 20 mins. 12.62 . New film on work of a county naturalists' trust.

Saiga Saga. Life history and conservation of the saiga antelope. Russian commentary with English titles. 16 minutes. $£ 2.62$. Presented by the Soviet Peace Committee.

Koala, by H. J. Pollock. Complete life history. 24 minutes. $£ 2.62$.

Marloo, the Red Kangaroo, by H. J. Pollock, 25 minutes. $£ 2.62$.

The Seals of Macquarie Island. Elephant and fur seals. 12 minutes.

Penguins of Macquarie Island. King, gentoo, rockhopper and royal penguins. 13 minutes.

The Mallee Fowl. The remarkable nesting story of a 'mound-builder'. 11 minutes.

Le Aye Aye de Madagascar, by J. J. Petter. Black and white, French commentary. 22 minutes. Presented by the Service du Film de Recherche Scientifique.

The Silent Watcher, by Eric Ashby, commentary by Peter Scott. Badgers, deer and foxes in the New Forest. Black and white, 35 minutes. $£ 2.16$.

The African Lion, by A. I. M. Hepburn. Taken in the Kruger National Park. Magnetic sound track. 12 minutes.

The Swallowtail Butterfly. The complete life story. 25 minutes.

\section{Silent Films with Captions}

Ceylon Wildlife, by C. E. Norris. Written commentary. 50 minutes.

Operation Oryx, by Michael Woodford. The FPS expedition. Black and white, 30 minutes.

* New copies of films formerly in the library. 